\title{
Accuracy of the clinical diagnosis of vascular dementia: a prospective clinical and post-mortem neuropathological study
}

\author{
T ERKINJUNTTI, M HALTIA, J PALO, R SUlKaVA, A PAETAU \\ From the Departments of Neurology and Pathology, University of Helsinki, Helsinki, Finland
}

SUMMARY Brains from a prospective study of demented patients were investigated post mortem. Of the 27 patients with clinical diagnosis of vascular dementia, 23 showed multiple cerebral infarcts but senile plaques and neurofibrillary tangles were absent or in insignificant numbers. This gives an accuracy of $85 \%$, a figure higher than previously documented.

The two most common causes of dementia are Alzheimer's disease and widespread ischaemic lesions of the brain, commonly referred to as multi-infarct dementia (MID). ${ }^{12}$ Dementia may also be due to a combination of these two conditions, ${ }^{34}$ and to a number of other disorders. ${ }^{5}$

Few studies have been published on the accuracy of the clinical diagnosis of these diseases as verified post mortem. ${ }^{6-12}$ For Alzheimer's disease the accuracy has varied from 52 to $85 \%^{6-12}$ and for multi-infarct dementia from 21 to $82 \% .^{6-81011}$ The low accuracy of the clinical diagnosis of multi-infarct dementia has led researchers to question the reliability of its antemortem diagnosis. ${ }^{1314}$

We carried out a post mortem neuropathological investigation of demented patients admitted to departments of internal medicine and neurology. The patients had all been subjected to extensive clinical investigations, including psychometric analysis and computed tomography of the head (CT). The value of CT scans and ischaemic scores ${ }^{415}$ in the differential diagnosis between Alzheimer's disease and multiinfarct dementia was also investigated.

\section{Patients and methods}

\section{Clinical evaluation}

This prospective study is a follow-up of 233 consecutively admitted patients recruited from a study on the frequency of

Address for reprint requests: Dr T Erkinjuntti, Department of Neurology, University of Helsinki, Haartmaninkatu 4, 00290 Helsinki, Finland.

Received 6 March 1987 and in revised form 29 June 1987. Accepted 6 July 1987 dementia among medical inpatients, ${ }^{16}$ and from a series of patients referred to our neurological outpatient department because of suspected dementia. ${ }^{17}$

The diagnosis of dementia was based in all cases on the results of neurological and neuropsychological examinations. ${ }^{18}$ The criteria for dementia used were as follows: ${ }^{19}$ (1) a cognitive decline sufficient to interfere with social and occupational functioning, and to cause inability to care for oneself; (2) evidence of global cognitive impairment, impairment of memory, and abstract thinking: and (3) absence of delirium or other conditions, such as intoxication, that may disturb alertness or cloud consciousness. The dementia was rated as mild, moderate or severe according to the social competence of the patient. ${ }^{16}$ Patients with mild dementia were unable to carry out more complex intellectual tasks but able to live at home with regular, not continuous, aid in daily activities. Patients with moderate dementia were unable to perform most tasks requiring memory and abstract thinking and were able to live at home only with continuous supervision and aid. Patients with severe dementia had difficulties even in simple intellectual tasks, needed continuous aid, and in most cases needed institutionalisation.

Clinical evaluation included a neurological examination, an interview with a close informant, a detailed history compiled from all available records, and extensive laboratory investigations, including cerebrospinal fluid, chest radiograph, electrocardiogram, electroencephalogram, and noncontrast CT of the brain as described in detail earlier. ${ }^{172021}$

The clinical criteria for the different types of dementia are listed in table 1. The criteria for Alzheimer's disease were those outlined by McKhann et al, ${ }^{22}$ and the criteria for vascular dementia (including combined vascular and degenerative dementia) were those of DSM-III. ${ }^{19}$ Patients fulfilling the criteria for vascular dementia were further divided into groups with multi-infarct dementia, vascular dementia of haemodynamic type, and probable vascular dementia based on clinical evaluation, including CT. ${ }^{1820}$ Patients with dementia due to other specific causes had clinical evidence of a specific condition (other than vascular) 


\section{Table 1 Clinical criteria for different types of dementia}

Alzheimer's disease 92

Dementia with insidious onset and progressive deteriorating course without any history, signs or symptoms of focal brain damage and without a history of laboratory findings referable to any other aetiology.

Vascular dementia (including combined degenerative and vascular dementia) ${ }^{19}$

Dementia with a history of focal or acute signs or symptoms referable to disturbed cerebral circulation.

Multi-infarct dementia $(M I D)^{18}$ Dementia evolving in connection with acute neurological symptoms and signs and/or findings on computed tomography indicating multiple cortical and/or deep vascular lesions of the brain.

Vascular dementia of haemodynamic type ${ }^{18}$ Dementia evolving in temporal connection with cardiac arrhythmias and systemic hypotension recorded at hospital.

Prohable vascular dementia $(P V D)^{18}$ Dementia clinically judged to be related to disturbances of the cerebral circulation without any clear temporal connection with the evolution of dementia or evidence of multiple vascular lesions on the computed tomography scan. This group includes patients with combined degenerative and vascular dementia.

Dementia due to other specific causes of dementia

Dementia evolving in temporal connection to some other specific disorder known to cause dementia.

judged to be causally or temporally connected with the evolution of dementia.

The clinical diagnoses were made by one of us (TE) before the neuropathological assessment. Hachinski's ischaemic score ${ }^{15}$ and that of Rosen $e t a l^{4}$ were also calculated for each patient, but were not used in the diagnostic classification.

The CT scans were evaluated without knowledge of the clinical diagnosis by two neuroradiologists. ${ }^{20}{ }^{21}$ Hypodense areas compatible with cerebral infarcts were recorded. White matter low attenuation (WMLA), defined as patchy or diffuse areas of decreased attenuation involving only the white matter areas, around frontal or occipital horns, or along the bodies of lateral ventricles were also recorded. The lesion was rated to be mild if there was any sign of WMLA extending less than one fourth of the total white matter area. Changes were moderate if WMLA was up to half of the white matter area, and severe if the WMLA extended over one half of the total white matter area. Cortical and central atrophy was estimated by visual inspection and rated as none, mild, moderate or severe.

By 31 December $1985,71(31 \%)$ of the 233 patients had died. They included 12 of the 68 patients with Alzheimer's disease, 51 of the 133 patients with vascular dementia, and eight of the 32 patients with dementia due to other causes.

\section{Neuropathological evaluation}

Brains for systematic neuropathological assessment were available from five ( $42 \%$ ) patients with Alzheimer's disease, from 27 patients $(53 \%)$ with vascular dementia, and from five patients with dementia due to other causes.

The brains were fixed by immersion in $4 \%$ phosphate buffered formaldehyde for not less than 6 weeks. The brain was fixed except for three patients with Alzheimer's disease (cases 28, 29,30), in whom the right cerebral hemisphere was separated and frozen and the left hemisphere fixed. The brains were weighed after fixation. After external inspection a cut was made through the mamillary bodies at right angles to the fronto-occipital axis of the brain and further slices were then cut in the coronal plane at $10 \mathrm{~mm}$ intervals.

Macroscopic infarcts were defined as cavitations or softenings. Their number and position were recorded, and their volume was calculated from serial photographs of the posterior surface of the coronal slices, using computer aided planimetry. In five cases $(2,6,14,16,18)$ the volume was calculated from direct measurement of the macroscopic infarcts in the brain sections. The degree of macroscopic status cribriformis in the white matter and the severity of atherosclerosis in the circle of Willis were visually rated as absent, mild, moderate or severe.

Large specimens for microscopy were taken from both temporal lobes, including the hippocampi, as well as from the left frontal, parietal and occipital lobes, including the area striata. Specimens were also taken from the mamillary bodies, hypothalamus, thalamus, internal capsule, globus pallidus, putamen, caudate nucleus, substantia innominata, external capsule, mesencephalon (including the substantia nigra and nucleus ruber), pons (including the locus coeruleus), medulla oblongata and left cerebellar hemisphere. Paraffin sections $10 \mu \mathrm{m}$ thick were stained with haematoxylin-eosin. Luxol fast blue/cresyl violet and Holmes' silver stain.

The frequencies of senile plaques (SP) and neurofibrillary tangles (NFT) ${ }^{323}$ were assessed in the neocortex (left frontal, temporal, parietal and occipital) and in the hippocampus in sections stained with Holmes' silver stain. This was done in two ways: by rating the impression gained $(0=a b s e n t$ or only occasional, $1=$ mild, 2 = moderate, $3=$ severe) on scanning the whole cortical area available, and by calculating the absolute numbers in five fields $(\times 200$, diameter $1.3 \mathrm{~mm}$, area $1.13 \mathrm{~mm}^{2}$ ) examined at random in the sections in question. Mild corresponded, on average, to $1.9 \mathrm{SPs}$ and 1.2 NFTs, moderate to $9.3 \mathrm{SPs}$ and $8.1 \mathrm{NFTs,}$ and severe to 16.0 SPs and 17.4 NFTs per field.

Microscopic infarcts were defined as focal necrotic or postnecrotic lesions, including focal cell loss with reactive macrophages and/or astrogliosis. They were systematically screened in all the slices available. Records were also made of the extent of cell loss and the presence of Lewy bodies in the substantia nigra on both sides.

The neuropathological diagnoses were made by a neuropathologist (MH) without knowledge of the clinical data or diagnosis. The neuropathological criteria for Alzheimer's disease were the presence in moderate to severe degree of both SPs and NFTs in at least some areas of the neocortex and hippocampus, without significant ischaemic or other specific lesions. ${ }^{349}$ The corresponding criteria for multiinfarct dementia were the presence of multiple ischaemic lesions in cortical or subcortical areas (or both), without the Alzheimer's disease-type changes defined above. ${ }^{34}$ Patients showing features of both Alzheimer's disease and multiinfarct dementia were diagnosed as having combined degenerative and vascular dementia (MIX).

The two-tailed $t$ test and the chi-squared test with Yates' correction were used in statistical comparisons. 
Table 2 Age, sex, brain weight, frequencies of senile plaques (SPs) and neurofibrillary tangles (NFTs), infarcts, degree of status cribriformis, degree of atherosclerosis of the circle of Willis, and neuropathological diagnoses in patients with the clinical diagnosis of multi-infarct dementia (MID), vascular dementia of haemodynamic type (HAEMO), and probable vascular dementia $(P V D)$

\begin{tabular}{|c|c|c|c|c|c|c|c|c|c|c|c|c|}
\hline \multirow[b]{2}{*}{$\begin{array}{l}\text { Case } \\
\text { no }\end{array}$} & \multirow[b]{2}{*}{$\begin{array}{l}\text { Sex } \\
\text { Age } \\
(y r)\end{array}$} & \multirow[b]{2}{*}{$\begin{array}{l}\text { Clinical } \\
\text { diagnosis }\end{array}$} & \multirow[b]{2}{*}{$\begin{array}{l}\text { Brain } \\
\text { weight } \\
(g)\end{array}$} & \multicolumn{2}{|l|}{$S P s^{*}$} & \multicolumn{2}{|l|}{$N F T s^{*}$} & \multicolumn{2}{|l|}{ Infarcts } & \multirow[b]{2}{*}{$\begin{array}{l}\text { Status } \dagger \\
\text { cribri- } \\
\text { formis }\end{array}$} & \multirow{2}{*}{$\begin{array}{l}\text { Athero-+ } \\
\text { sclerosis } \\
\text { of the } \\
\text { circle of } \\
\text { Willis }\end{array}$} & \multirow[b]{2}{*}{$\begin{array}{l}\text { Neuropathological } \\
\text { diagnosis }\end{array}$} \\
\hline & & & & $\begin{array}{l}\text { Neo- } \\
\text { cortex }\end{array}$ & $\begin{array}{l}\text { Hippo- } \\
\text { campus }\end{array}$ & $\begin{array}{l}\text { Neo- } \\
\text { cortex }\end{array}$ & $\begin{array}{l}\text { Hippo- } \\
\text { campus }\end{array}$ & $\begin{array}{l}\text { Number } \\
\text { All/ } \\
\text { macrosc }\end{array}$ & $\begin{array}{l}\text { Volume } \\
(\mathrm{ml})\end{array}$ & & & \\
\hline 1 & $F, 75$ & MID & 1002 & 0 & 0 & 0 & 0 & $6 / 5$ & 20 & 2 & 3 & MID \\
\hline 2 & $\mathbf{M}, 85$ & MID & 1100 & 1.8 & 0 & 0 & 0 & $3 / 3$ & 23 & 0 & 2 & MID \\
\hline 3 & $F, 85$ & MID & 930 & 0 & 0 & 0 & 0 & $3 / 3$ & 9 & 1 & 3 & MID \\
\hline 4 & F, 74 & MID & 1076 & 0 & 0 & 0 & 0 & $5 / 5$ & 12 & 2 & 2 & MID \\
\hline 5 & F, 84 & MID & 1150 & $4 \cdot 2$ & $2 \cdot 8$ & 0 & 0 & $5 / 4$ & 24 & 0 & 3 & MID \\
\hline 6 & F, 76 & MID & 1009 & 0 & 0 & 0 & 0 & $8 / 7$ & 20 & 2 & 3 & MID \\
\hline 7 & $\mathbf{M}, 79$ & MID & 1237 & 0.2 & 0 & 0 & 0 & $8 / 7$ & 20 & 1 & 3 & MID \\
\hline 8 & $\mathbf{M}, 81$ & MID & 1222 & 0 & 0 & 0 & 0 & $7 / 4$ & 6 & 2 & 2 & MID \\
\hline 9 & $F, 84$ & MID & 1035 & 0.3 & 0 & 0 & 0.6 & $9 / 6$ & 24 & 2 & 2 & MID \\
\hline 10 & F, 92 & MID & 881 & 0.7 & 0 & 0 & 0 & $2 / 2$ & 229 & 0 & 2 & MID \\
\hline 11 & $F, 64$ & MID & 1018 & 0 & 0 & 0 & 0 & $9 / 7$ & 13 & 2 & 3 & MID \\
\hline 12 & $F, 75$ & MID & 1100 & 0 & 0 & 0 & 0 & $5 / 4$ & 124 & 2 & 2 & MID \\
\hline 13 & F, 88 & MID & 961 & 0 & 0 & 0 & 0 & $8 / 5$ & 56 & 3 & 3 & MID \\
\hline 14 & $\mathbf{M}, 77$ & MID & 1230 & 0.5 & $1 \cdot 8$ & 0 & 0 & $4 / 1$ & 32 & 0 & 2 & MID \\
\hline 15 & $\mathrm{~F}, 71$ & MID & 958 & 0 & 0 & 0 & 0 & $2 / 2$ & 127 & 1 & 1 & MID \\
\hline 16 & $F, 82$ & MID & 1195 & 0.4 & 0 & 0 & 0 & $8 / 7$ & 6 & i & 3 & MID \\
\hline 17 & M, 61 & MID & 1427 & 0 & 0 & 0 & 0 & $4 / 0$ & 1 & 2 & 3 & MID \\
\hline 18 & F, 92 & MID & 1050 & 1.0 & $1 \cdot 2$ & 0 & 0.2 & $2 / 2$ & $i$ & 1 & 2 & UNDEFINED \\
\hline 19 & F, 81 & MID & 1142 & 0.9 & $2 \cdot 0$ & 1.9 & $7 \cdot 4$ & $3 / 3$ & 18 & 1 & 1 & MIX§ \\
\hline 20 & M, 79 & HAEMO & 1066 & 0 & 0 & 0 & 0 & $8 / 7$ & 84 & 3 & 3 & MID \\
\hline 21 & $F, 88$ & HAEMO & 1162 & 0 & 0 & 0 & 0 & $3 / 2$ & 38 & 0 & 1 & MID \\
\hline 22 & M, 77 & HAEMO & 1080 & 0 & 0 & 0 & 0 & $6 / 6$ & 2 & 3 & 2 & MID \\
\hline 23 & F, 87 & PVD & 884 & $10 \cdot 5$ & 8.6 & 0 & $12 \cdot 8$ & $2 / 0$ & $<1$ & 2 & 2 & MIX \\
\hline 24 & $\mathrm{M}, 78$ & PVD & 1199 & $5 \cdot 5$ & 9.8 & $2 \cdot 5$ & 14.8 & $1 / 0$ & $<1$ & 2 & 3 & MIX \\
\hline 25 & M, 79 & PVD & 1221 & 0 & 0 & 0 & 1.8 & $6 / 2$ & 1 & 2 & 3 & MID \\
\hline 26 & M, 86 & PVD & 1049 & 0 & 0 & 0 & 0 & $5 / 2$ & 6 & 2 & 3 & MID \\
\hline 27 & $F, 80$ & PVD & 1050 & 0 & 0 & 0 & 0 & $7 / 4$ & 24 & 2 & 2 & MID \\
\hline
\end{tabular}

*Mean number per microscope field $\times 200$, diameter $1.3 \mathrm{~mm}$, Holmes' silver stain.

t0 $=$ none, $1=$ mild, $2=$ moderate, $3=$ severe.

$+1=$ mild, $2=$ moderate, $3=$ severe.

$\S \mathrm{MIX}=$ mixed type (combined vascular and degenerative)

Table 3 Age, sex, brain weight, frequencies of senile plaques (SPs) and neurofibrillary tangles (NFTs), infarcts, degree of status cribriformis, degree of atherosclerosis of the circle of Willis, presence of Lewy bodies in the substantia nigra, and neuropathological diagnoses in patients with the clinical diagnosis of Alzheimer's disease (AD) and specific cause of dementia (SPEC). (See comments and details in text)

\begin{tabular}{|c|c|c|c|c|c|c|c|c|c|c|c|c|c|}
\hline \multirow[b]{2}{*}{$\begin{array}{l}\text { Case } \\
\text { no }\end{array}$} & \multirow[b]{2}{*}{$\begin{array}{l}\text { Sex } \\
\text { Age } \\
(y r)\end{array}$} & \multirow[b]{2}{*}{$\begin{array}{l}\text { Clinical } \\
\text { diagnosis }\end{array}$} & \multirow[b]{2}{*}{$\begin{array}{l}\text { Brain } \\
\text { weight } \\
\text { (g) }\end{array}$} & \multicolumn{2}{|l|}{$S P s^{*}$} & \multicolumn{2}{|l|}{$N F T s^{*}$} & \multicolumn{2}{|l|}{ Infarcts } & \multirow[b]{2}{*}{$\begin{array}{l}\text { Statust } \\
\text { cribri- } \\
\text { formis }\end{array}$} & \multirow{2}{*}{$\begin{array}{l}\text { Athero-† } \\
\text { sclerosis } \\
\text { of the } \\
\text { circle of } \\
\text { Willis }\end{array}$} & \multirow[b]{2}{*}{$\begin{array}{l}\text { S. nigra } \\
\text { Lewy } \\
\text { bodies }\end{array}$} & \multirow[b]{2}{*}{$\begin{array}{l}\text { Neuropathological } \\
\text { diagnosis }\end{array}$} \\
\hline & & & & $\begin{array}{l}\text { Neo- } \\
\text { cortex }\end{array}$ & $\begin{array}{l}\text { Hippo- } \\
\text { campus }\end{array}$ & $\begin{array}{l}\text { Neo- } \\
\text { cortex }\end{array}$ & $\begin{array}{l}\text { Hippo- } \\
\text { campus }\end{array}$ & $\begin{array}{l}\text { Number } \\
\text { All/ } \\
\text { macrosc }\end{array}$ & $\begin{array}{l}\text { Volume } \\
(\mathrm{ml})\end{array}$ & & & & \\
\hline $\begin{array}{l}28 \\
29 \\
30 \\
31 \\
32 \\
33 \\
34 \\
35 \\
36 \\
37\end{array}$ & $\begin{array}{l}\text { M, } 70 \\
\text { F, 77 } \\
M, 57 \\
M, 83 \\
F, 82 \\
M, 75 \\
F, 80 \\
M, 81 \\
F, 83 \\
F, 74\end{array}$ & $\begin{array}{l}\text { AD } \\
\text { AD } \\
\text { AD } \\
\text { AD } \\
\text { AD } \\
\text { SPEC } \\
\text { SPEC } \\
\text { SPEC } \\
\text { SPEC } \\
\text { SPEC }\end{array}$ & $\begin{array}{l}1030 \| \\
1255 \| \\
1230 \| \\
1370 \\
1150 \\
1400 \\
1075 \\
1380 \\
1040 \\
1065\end{array}$ & $\begin{array}{c}17 \cdot 3 \\
4 \cdot 4 \\
9 \cdot 4 \\
6 \cdot 7 \\
5 \cdot 5 \\
0 \\
0 \\
3 \cdot 5 \\
0 \\
0\end{array}$ & $\begin{array}{c}11 \cdot 6 \\
9 \cdot 4 \\
10 \cdot 2 \\
8 \cdot 2 \\
1 \cdot 6 \\
0 \\
0 \\
2 \cdot 2 \\
0 \\
1 \cdot 4\end{array}$ & $\begin{array}{l}9 \cdot 9 \\
1 \cdot 6 \\
11 \cdot 8 \\
2 \cdot 1 \\
1 \cdot 8 \\
0 \\
0 \\
2 \cdot 9 \\
0 \\
0\end{array}$ & $\begin{array}{r}22 \cdot 8 \\
33 \cdot 0 \\
9 \cdot 4 \\
8 \cdot 8 \\
1 \cdot 8 \\
0 \\
1 \cdot 4 \\
1 \cdot 8 \\
0 \\
0\end{array}$ & $\begin{array}{l}0 / 0 \\
0 / 0 \\
0 / 0 \\
0 / 0 \\
1 / 0 \\
0 / 0 \\
7 / 4 \\
0 / 0 \\
2 / 0 \\
7 / 6\end{array}$ & $\begin{array}{l}\overline{-} \\
\overline{-} \\
\overline{<1} \\
\overline{42} \\
\overline{<1} \\
14\end{array}$ & $\begin{array}{l}0 \\
0 \\
1 \\
0 \\
0 \\
0 \\
1 \\
0 \\
1 \\
2\end{array}$ & $\begin{array}{l}1 \\
1 \\
1 \\
1 \\
1 \\
1 \\
2 \\
1 \\
1 \\
3\end{array}$ & $\begin{array}{l}\overline{-} \\
\overline{-} \\
\overline{+} \\
\frac{ \pm}{+} \\
-\end{array}$ & $\begin{array}{l}\text { AD } \\
\text { AD } \\
\text { AD } \\
\text { AD } \\
\text { AD } \\
\text { PD } \\
\text { MID } \\
\text { PD + AD } \\
\text { UNDEFINED } \\
\text { MID }\end{array}$ \\
\hline
\end{tabular}

*Mean number per microscope field $\times 200$, diameter $1.3 \mathrm{~mm}$, Holmes' silver stain.

to $=$ none, $1=$ mild, $2=$ moderate, $3=$ severe.

$\ddagger 1=$ mild, 2 = moderate, 3 = severe.

$\S \mathrm{PD}=$ Parkinson's disease

$\|$ Calculated assuming that the right and left cerebral hemisphere were equal in weight. 
Table 4 Rating and counts/field of senile plaques (SPS) and neurofibrillary tangles (NFTs) (mean \pm sem) per microscope field $(\times 200$, diameter $1.3 \mathrm{~mm}$, Holmes' silver stain), number of infarcts and mean brain weight in patients with the neuropathological diagnosis of multi-infarct dementia (MID), combined degenerative and vascular dementia (MIX), and Alzheimer's disease ( $A D$ )

\begin{tabular}{|c|c|c|c|c|}
\hline & & $M I D(N=23)$ & $M I X(N=3)$ & $A D(N=5)$ \\
\hline SPs & Rating & $0.1 \pm 0.1$ & $1 \cdot 3 \pm 0.4$ & $2 \cdot 0 \pm 0.3$ \\
\hline SPs & $\begin{array}{l}\text { Number } \\
\text { Rating }\end{array}$ & $\begin{array}{l}0.3 \pm 0.2 \\
0.1 \pm 0.1\end{array}$ & $\begin{array}{l}5.6 \pm 2.8 \\
1.7 \pm 0.3\end{array}$ & $\begin{array}{l}8 \cdot 7 \pm 2 \cdot 3 \\
2 \cdot 0 \pm 0.3\end{array}$ \\
\hline $\begin{array}{l}\text { NFTs } \\
\text { neocortex }\end{array}$ & $\begin{array}{l}\text { Number } \\
\text { Rating }\end{array}$ & $\begin{array}{l}0 \cdot 2 \pm 0 \cdot 1 \\
0 \cdot 0\end{array}$ & $\begin{array}{l}6 \cdot 8 \pm 2 \cdot 4 \\
0 \cdot 5 \pm 0.3\end{array}$ & $\begin{array}{l}8 \cdot 2 \pm 1 \cdot 7 \\
1.4 \pm 0.4\end{array}$ \\
\hline $\begin{array}{l}\text { NFTs } \\
\text { hippocampus }\end{array}$ & $\begin{array}{l}\text { Number } \\
\text { Rating }\end{array}$ & $\begin{array}{l}0 \cdot 0 \\
0 \cdot 1 \pm 0 \cdot 1\end{array}$ & $\begin{array}{l}1 \cdot 5 \pm 2 \cdot 3 \\
2 \cdot 0 \pm 0.0\end{array}$ & $\begin{array}{l}5 \cdot 2 \pm 2 \cdot 3 \\
2 \cdot 2 \pm 0 \cdot 4\end{array}$ \\
\hline $\begin{array}{l}\text { Infarcts } \\
\text { Brain weight (g) }\end{array}$ & $\begin{array}{l}\text { Number } \\
\text { Mumber }\end{array}$ & $\begin{array}{r}0.1 \pm 0.1 \\
5.7 \pm 0.5 \\
1093.9+25.9\end{array}$ & $\begin{array}{r}11.7 \pm 2.2 \\
2.0 \pm 0.6 \\
1075.0 \pm 96.9\end{array}$ & $\begin{array}{r}15.2 \pm 5.6 \\
0.2 \pm 0.2 \\
1207.0 \pm 56.6\end{array}$ \\
\hline
\end{tabular}

\section{Results}

\section{Neuropatholngical diagnosis}

Of the 27 patients with a clinical diagnosis of vascular dementia, 23 fulfilled the neuropathological criteria for multi-infarct dementia (table 2). They all showed multiple ischaemic lesions and few if any SPs and NFTs. Three cases showed features of both multiinfarct dementia and Alzheimer's disease, and they were diagnosed as MIX. The remaining case (18) had bilateral lacunar infarcts in the putamen extending to the substantia innominata, severe atrophy of the right hippocampus, and a few SPs and NFTs. The neuropathological diagnosis remained undefined.

All five patients with a clinical diagnosis of Alzheimer's disease had SPs and NFTs of moderate to severe degree in at least some areas of the neocortex and hippocampus (table 3). One patient (case 32) had one microscopic infarct in the left temporal white matter but no other signs of ischaemia. All these patients were diagnosed neuropathologically as having Alzheimer's disease.

Of the five patients presenting with other causes of dementia two (33 and 35 ) were diagnosed clinically as

Table 5 The most important clinical characteristics of patients with the neuropathological diagnosis of multi-infarct dementia (MID), combined degenerative and vascular dementia (MIX), and Alzheimer's disease (AD)

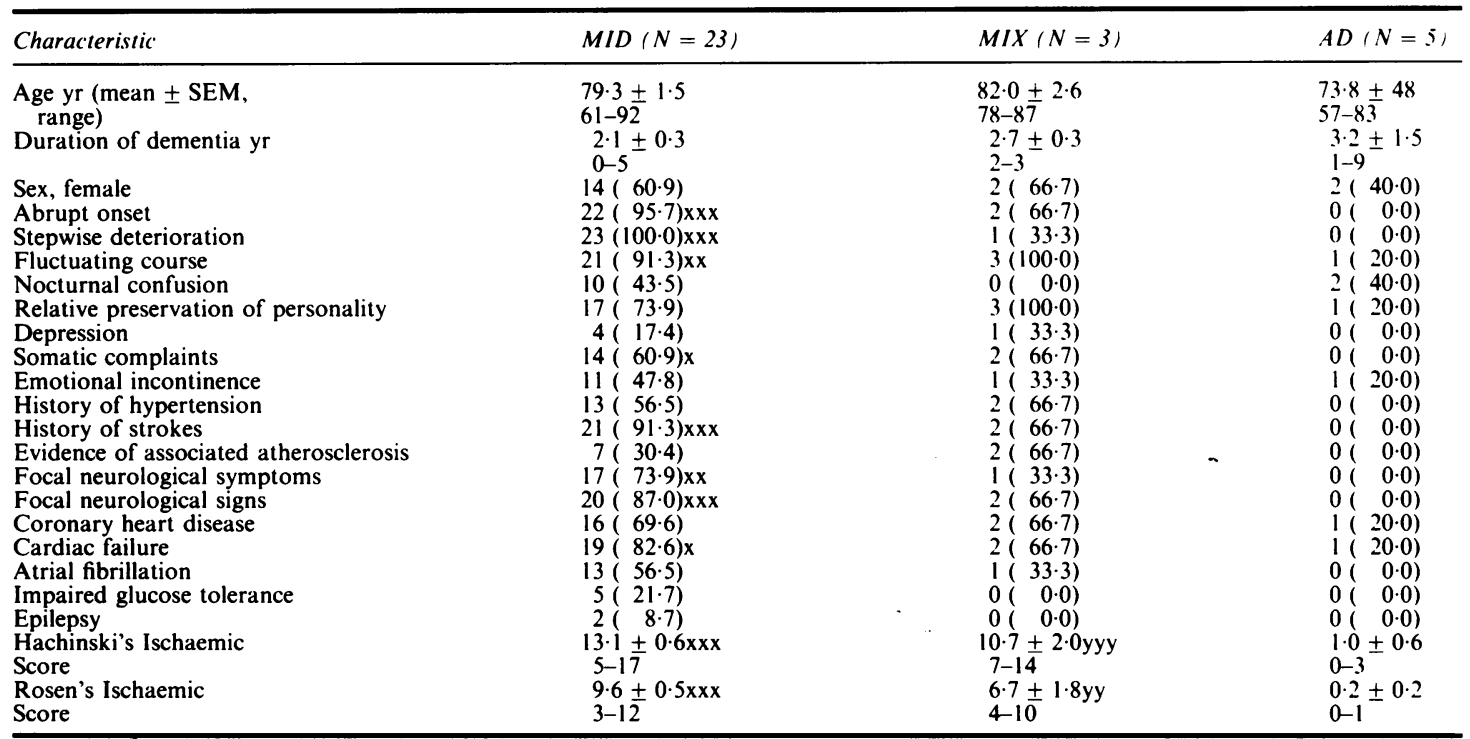

MID vs AD: $x x x=p<0.001, x x=p<0.01, x=p<0.05$.

MIX vs: $y y y=p<0.001$. $y y=p<0.01$. 
Table 6 Presence of infarcts, white matter low attenuation (WMLA), cortical atrophy and central atrophy seen on CT scans in patients with the neuropathological diagnosis of multi-infarct dementia (MID), combined degenerative and vascular dementia $(M I X)$, and Alzheimer's disease ( $A D)$ (percentage in parenthesis)

\begin{tabular}{|c|c|c|c|}
\hline & $M I D(N=23)$ & $M I X(N=3)$ & $A D(N=5)$ \\
\hline $\begin{array}{l}\text { Cortical infarct } \\
\text { Deep infarct } \\
\text { Any WMLA }\end{array}$ & $\begin{array}{l}17(73.9) \times x \\
3(13.0) \\
19(82.6) x, z\end{array}$ & 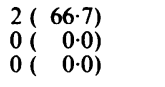 & 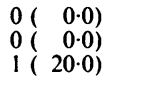 \\
\hline $\begin{array}{l}\text { WMLA frontal } \\
\text { no } \\
\text { mild } \\
\text { moderate } \\
\text { severe }\end{array}$ & $\begin{aligned} 4 & (17 \cdot 4) \times x . z \\
11 & (47 \cdot 8) \\
7 & (30 \cdot 4) \\
1 & (4 \cdot 3)\end{aligned}$ & 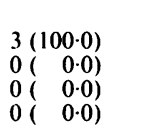 & 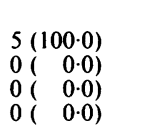 \\
\hline $\begin{array}{l}\text { WMLA paraventricular } \\
\text { no } \\
\text { mild } \\
\text { moderate } \\
\text { severe }\end{array}$ & $\begin{array}{r}10(43.5) \\
8(34.8) \\
4(17 \cdot 4) \\
1(4.3)\end{array}$ & 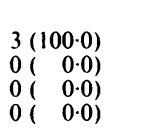 & 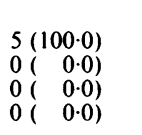 \\
\hline $\begin{array}{l}\text { WMLA occipital } \\
\text { no } \\
\text { mild } \\
\text { moderate } \\
\text { severe }\end{array}$ & $\begin{aligned} 4 & (17 \cdot 4) \times, z \\
12 & (52 \cdot 2) \\
6 & (26 \cdot 1) \\
1 & (4 \cdot 3)\end{aligned}$ & 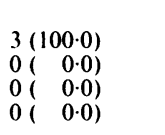 & 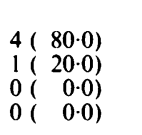 \\
\hline $\begin{array}{l}\text { Cortical atrophy } \\
\text { no } \\
\text { mild } \\
\text { moderate } \\
\text { severe }\end{array}$ & $\begin{array}{l}0(0 \cdot 0) \\
6(26 \cdot 1) \\
9(39 \cdot 1) \\
8(34 \cdot 8)\end{array}$ & 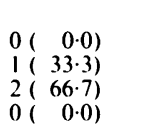 & 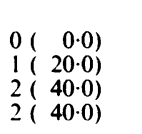 \\
\hline $\begin{array}{l}\text { Central atrophy } \\
\text { no } \\
\text { mild } \\
\text { moderate } \\
\text { severe }\end{array}$ & $\begin{array}{l}0(0.0) z \\
11(47 \cdot 8) \\
8(34 \cdot 8) \\
4(17 \cdot 4)\end{array}$ & 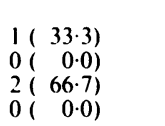 & 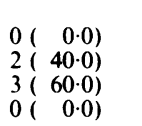 \\
\hline
\end{tabular}

*Along the bodies of lateral ventricles

MID vs AD: $x x=p<0.01, x=p<0.05$. MID vs MIX: $z=p<0.05$

Parkinson's disease (table 3 ). In both brains moderate cell loss was found and Lewy bodies were present in the substantia nigra. Case 35 had additional Alzheimer's disease changes and the diagnosis was changed to combined Parkinson's disease and Alzheimer's disease. In case 34 dementia developed in temporal connection with severe hyperthyroidism, although the patient also had clinical signs of a stroke. The neuropathological findings were compatible with multi-infarct dementia. Case 37 had vitamin B12 deficiency and stroke, with multi-infarct dementia changes at necropsy. These two patients were excluded from the multi-infarct dementia group in further analyses. Case 36 had a small frontal meningioma besides microscopic cortical infarcts found postmortem. The diagnosis remained undefined.

Frequency of SPs, NFTs and infarcts in patients with neuropathological diagnosis of multi-infarct dementia, MIX and Alzheimer's disease are given in table 4 . The mean volume of macroscopically defined infarcts was $39 \mathrm{ml}$ (range 1 to $229 \mathrm{ml}$ ) in multi-infarct dementia and $6 \mathrm{ml}(<1$ to $18 \mathrm{ml})$ in MIX. The only infarct found in Alzheimer's disease had a volume of less than $1 \mathrm{ml}$. The degree of macroscopic status cribriformis $(p<0.05)$ and atherosclerosis in the circle of Willis $(p<0.001)$ also differentiated multiinfarct dementia from Alzheimer's disease (tables 2 and 3). Brain weights did not differ significantly between the patients with multi-infarct dementia, Alzheimer's disease and MIX (table 4).

\section{Accuracy of clinical diagnosis}

The accuracy of the clinical diagnosis of vascular dementia, as confirmed post mortem, was $85 \%$ ( 23 of 27). For patients diagnosed as having multi-infarct dementia it was $89 \%$ (17 of 19). All the patients with vascular dementia of haemodynamic type showed the neuropathological changes characteristic of multi-infarct dementia, while two of the five patients with probable vascular dementia had additional Alzheimer's disease changes. All the patients with Alzheimer's disease were correctly diagnosed during life.

Characteristics of infarcts in multi-infarct dementia Of the 23 patients with a neuropathological diagnosis of multi-infarct dementia, $22(96 \%)$ had bilateral infarcts. In case 10, with lesions in the right hemi- 
sphere only, the infarcts were extensive (total volume $229 \mathrm{ml}$ ). Frontal infarcts were seen in 13 patients $(56 \%)$, temporal in $21(91 \%)$, parietal in $15(65 \%)$, occipital in $14(61 \%)$, and hippocampal in $11(48 \%)$. Half the infarcts $(52 \%)$ were found in the left hemisphere. In $19(83 \%)$ patients infarcts were found in the basal ganglia (in the putamen in 19, in the globus pallidus in seven and in the caudate nucleus in three).

The dementia was mild in four, moderate in nine and severe in 10 of the patients with multi-infarct dementia. The mean interval between clinical evalution and necropsy was comparable in the three groups, 330, 354 and 213 days, respectively. The mean numbers of infarcts were also similar: mild 6 (4 to 8), moderate 7 (5 to 9 ) and severe 5 (2 to 8 ). The mean total volume of infarcted tissue tended to increase with increasing severity of the dementia: mild $3 \mathrm{ml}$ (range 1 to 6), moderate $29 \mathrm{ml}(6$ to 124$)$ and severe $63 \mathrm{ml}$ (6 to 229). The degree of macroscopic status cribriformis was not related to the degree of dementia.

\section{The most important clinical features in the} neuropathologically confirmed cases

Neither mean age nor duration of dementia nor sex differentiated the patients with multi-infarct dementia, MIX and Alzheimer's disease (table 5). Hachinski's ischaemic score and that of Rosen et al differentiated multi-infarct dementia and MIX from Alzheimer's disease, but not multi-infarct dementia from MIX. Six ischaemic score items (abrupt onset, stepwise deterioration, fluctuating course, somatic complaints, a history of strokes, and focal neurological symptoms and signs) differentiated multiinfarct dementia from Alzheimer's disease, but not MIX from Alzheimer's disease or multi-infarct dementia. Furthermore, a history of hypertension, coronary heart disease, cardiac failure and atrial fibrillation tended to be more frequent in multi-infarct dementia than in Alzheimer's disease. Presence of infarcts and white matter low attenuation seen on CT also differentiated multi-infarct dementia from Alzheimer's disease, but not degree of cortical or central atrophy (table 6).

\section{Discussion}

The patients included in the present prospective study were recruited from the departments of internal medicine and neurology. The series was therefore not randomly selected, and consequently no epidemiological conclusion can be drawn. The same is true of many other necropsy reports on dementia. 346-12 24-26 The origin of the series explains why cases of vascular dementia outnumbered those of Alzheimer's disease, despite the higher prevalence of Alzheimer's disease in epidemiological surveys. ${ }^{127}$ The reason is that acute cardio- and cerebrovascular episodes bring these patients more often to a hospital with an emergency service. $^{1617}$

Selection of the neuropathological diagnosis was based on the dominant pathological process, as in the study of Tomlinson et al. ${ }^{3}$ The neuropathological criteria for Alzheimer's disease ${ }^{349}$ and multi-infarct dementia $^{34}$ are those commonly used. The neuropathological diagnosis of Alzheimer's disease accords with the criteria of Khachaturian et al. ${ }^{28}$ The numbers of SPs and NFTs seen in some of the patients with multi-infarct dementia may also be found in normal aging. ${ }^{29}$

This is the first large-scale prospective study on the accuracy of the clinical diagnosis of vascular dementia since the advent of CT. The accuracy of the clinical diagnosis for the whole group of vascular dementia was $85 \%$. For multi-infarct dementia it was $89 \%$, for vascular dementia of haemodynamic type $100 \%$, and for probable vascular dementia $60 \%$ in regard to multi-infarct dementia. In the small series of Alzheimer's disease it was also $100 \%$. Ischaemic brain lesions were the most probable cause of dementia in the patients with multi-infarct dementia because other causes were excluded, and neurofibrillary tangles and senile plaques, if present, were insignificant in number. Every patient had two or more distinct $\mathbb{\Phi}$ infarcts, the mean number being six. Loss of brain volume due to infarcts has been regarded as the dominant mechanism leading to multi-infarct dementia. ${ }^{3}$ In the present series the mean loss due to macroscopically defined infarcts was $39 \mathrm{ml}$, but it ranged from 1 to $229 \mathrm{ml}$. The mean total volume of the infarcts, measured in actual size, was smaller than in the only other comparable study, in which it was $186 \mathrm{ml}^{3}{ }^{3}$ This may be due to differences in methodology, but other factors may also be involved.

The mean volume of infarcts increased with the severity of the dementia, a finding that is in agreement with the results of Tomlinson et al, ${ }^{3}$ but different from those of Rothschild. ${ }^{30}$ Small infarcts are a frequent finding in non-demented old people, ${ }^{29}$ indicating that their topography may be important. Of the patients with multi-infarct dementia, $96 \%$ showed bilateral infarcts, $91 \%$ temporal infarcts, and $83 \%$ infarcts in the basal ganglia.

White matter changes may be a contributing factor in the evolution of multi-infarct dementia. ${ }^{31}$ Macroscopic status cribriformis was seen in $78 \%$ of the patients with multi-infarct dementia. None of the cases presented a pure neuropathological picture of the lacunar state or Binswanger's disease.$^{32-34}$ However, in two patients (19 and 22) the ischaemic lesions were more accentuated in the white matter and basal ganglia. These cases represented $9 \%$ of the multi- 
infarct dementia patients; the corresponding figure reported by Rothschild was $11 \%$. $^{30}$

All patients with vascular dementia of haemodynamic type fulfilled the neuropathological criteria for multi-infarct dementia. The role of cardiac arrhythmia and hypotension in the evolution of dementia has been questioned by some ${ }^{35}$ and supported by others. ${ }^{36-39}$ Haemodynamic mechanisms may also play a role in other types of vascular dementia, so that treating the haemodynamic type as separate clinical entity is questionable.

Three patients showed neuropathological features of both Alzheimer's disease and multi-infarct dementia. In Alzheimer's disease vascular lesions of limited extent may express themselves as abrupt onset, fluctuating course or focal neurological symptoms and signs, because the brain's reserve capacity is already limited by the degenerative changes. ${ }^{40}$ These cases are probably usually diagnosed as MIX or multi-infarct dementia, and the clinical diagnoses are likely to over-emphasise the role of cerebral infarcts. ${ }^{31440}$ Thus, the clinical differentiation of MIX from multi-infarct dementia and also from Alzheimer's disease presents even today some difficulties.

Abrupt onset, stepwise deterioration of cognitive function, a history of strokes, and the presence of focal neurological symptoms and signs differentiated between patients with multi-infarct dementia and Alzheimer's disease. These items were also of primary importance in the series of Rosen et $\mathrm{al} .{ }^{4}$ In contrast to our findings, Mölsä et $a l^{10}$ reported no differences in abrupt onset and focal neurological signs, and Alafuzoff ${ }^{11}$ found no differences in focal neurological symptoms and signs between Alzheimer's disease and multi-infarct dementia. As reported earlier, a fluctuating course.$^{10}$ relative preservation of personality, ${ }^{610}$ somatic complaints, ${ }^{30}$ and emotional incontinence 461030 seemed to be more common in neuropathological confirmed multi-infarct dementia than in Alzheimer's disease, but this was not true of nocturnal confusion and depression. A history of hypertension, cardiac failure, and ischaemic heart disease tended to be more common in multi-infarct dementia than in Alzheimer's disease, findings also reported previously. ${ }^{4142}$

Infarcts and white matter low attenuation, but not degree of cortical or central atrophy, seen on the CT scan differentiated multi-infarct dementia from Alzheimer's disease, a finding not previously documented in a neuropathologically verified series. Addition of CT data to the ischaemic scores would therefore seem justified. ${ }^{43}$ In general, our results confirm the usefulness of ischaemic scores ${ }^{415}$ as aids in the differential diagnosis between multi-infarct dementia and Alzheimer's disease. However, as reported previously, the MIX cases are not reliably differentiated from these two conditions. ${ }^{410}$ This supports the idea of using clinical scores ${ }^{44}$ or other future methods for Alzheimer's disease once they become available.

This study was supported by the University of Helsinki Central Hospital, the Medical Research Council of the Academy of Finland, the Neurology Foundation, and the Yrjö Jahnsson Foundation. We thank Drs Leena Ketonen and Matti Vuorialho for analysis of the CT findings, Ms Ritva Laaksonen, MA, for neuropsychological assessment of the patients, and Ms Marjatta Kivekäs for technical assistance. The language of the manuscript was checked by Mrs Jean Margaret Perttunen.

\section{References}

1 Sulkava R, Wilkström J, Aromaa A, et al. Prevalence of severe dementia in Finland. Neurology 1985;35:1025-9.

2 Hachinski VC, Lassen NA, Marshall J. Multi-infarct dementia. A cause of mental deterioration in the elderly. Lancet 1974; ii: $207-10$.

3 Tomlinson BE, Blessed G, Roth M. Observations on the brains of demented old people. J Neurol Sci 1979;11:205-42.

4 Rosen WG, Terry RD, Fuld PA, Karzman R, Peck A. Pathological verification of ischaemic score in differentiation of dementias. Ann Neurol 1980;7:486-8

5 Barret RE. Dementia in adults. Med Clin North Am 1972; 56:1405-18.

6 Birkett DP. The psychiatric differentiation of senility and arteriosclerosis. Br J Psychiatry 1972;120:321-5.

7 Todorov AB, Go RCP, Constantinidis J, Elston RC. Specificity of the clinical diagnosis of dementia. J Neurol Sci 1975; 26:81-98.

8 Müller HF. Schwartz G. Electroencephalograms and autopsy findings in geropsychiatry. $J$ Gerontol 1978;33:504-13.

9 Sulkava R, Haltia M, Paetau A, Wilkström J, Palo J. Accuracy of clinical diagnosis in primary degenerative dementia: correlation with neuropathological findings. $J$ Neurol Neurosurg Psychiatry 1983;46:9-13.

10 Mölsä PK, Paljärvi L, Rinne JO, Rinne UK, Säkö E. Validity of clinical diagnosis in dementia: A prospective clinicopathological study. J Neurol Neurosurg Psychiatry 1985; 48: $1085-90$.

11 Alafuzoff I. Histopathological and immunocytochemical studies in age-associated dementias. Dissertation. Umeå University, Umeå, $1985,91$.

12 Wade JPH, Mirsen TR, Hachinski VC, Fisman M, Lau C, Merskey H. The clinical diagnosis of Alzheimer's disease. Arch Neurol 1987;44:24-9.

13 Liston EH, La Rue A. Clinical differentiation of primary degenerative and multi-infarct dementia: a critical review of the evidence. Part II: Pathological studies. Biol Psychiatry 1983, 18: 1467-84.

14 Brust JCM. Vascular dementia-still overdiagnosed. Stroke 1983:14:298-300.

15 Hachinski VC, Iliff LD, Zilhka E, et al. Cerebral blood flow in dementia. Arch Neurol 1975;32:632-7.

16 Erkinjuntti T, Wikström J, Palo J, Autio L. Dementia among medical inpatients. Evaluation of 2000 consecutive admissions. Arch Intern Med 1986;147:1923-6.

17 Erkinjuntti T, Sulkava R, Kovanen J, Palo J. Suspected dementia: evaluation of 323 consecutive patients referred to a 
neurologic outpatient department. Acta Neurol Scand 1987; 76:359-64.

18 Erkinjuntti T, Laaksonen R, Sulkava R, Syrjäläinen R, Palo J. Neuropsychological differentiation between normal aging, Alzheimer's disease and vascular dementia. Acta Neurol Scand 1986;74:393-403.

19 American Psychiatric Association. Diagnostic and Statistical Manual of Mental Disorders. 3rd ed, APA: Washington DC, 1980.

20 Erkinjuntti T, Ketonen L, Sulkava R, Vuorialho M, Palo J. CT in the differential diagnosis between Alzheimer's disease and vascular dementia. Acta Neurol Scand 1987;75:262-70.

21 Erkinjuntti T, Ketonen L, Sulkava R, Sipponen J, Vuorialho M, Iivanainen $M$. Do white matter changes on MRI and CT differentiate vascular dementia from Alzheimer's disease? $J$ Neurol Neurosurg Psychiatry 1987;50:37-42.

22 McKhann G, Drachman D, Folstein M, Katzman R, Price D, Stadlen EM. Clinical diagnosis of Alzheimer's disease: Report of the NINCDS-ADRDA Work Group under the auspices of Department of Health and Human Services Task Force on Alzheimer's disease. Neurology 1984;34:939-44.

23 Terry RD, Katzman R. Senile dementia of the Alzheimer type. Ann Neurol 1983;14:497-506.

24 Jellinger K. Neuropathological aspects of dementias resulting from abnormal blood and cerebrospinal fluid dynamics. Acta Neurol Belg 1976;76:83-102.

25 Malamud N. Neuropathology of organic brain syndromes associated with aging. In: Gaitz CM, ed. Aging and the Brain. New York: Plenum, 1972;63-87.

26 Corsellis JAN. Mental Illness and the Ageing Brain. London: Oxford University Press 1962.

27 Kay DWK, Beamish P, Roth M. Old age mental disorders in Newcastle-upon-Tyne. Part I: A study of prevalence. $B r J$ Psychiatry 1964;110:146-58.

28 Khachaturian ZS. Diagnosis of Alzheimer's disease. Arch Neurol 1985;42:1097-105.

29 Tomlinson BE, Blessed G, Roth M. Observations on the brains of non-demented old people. J Neurol Sci 1968;7:331-56.

30 Rothschild D. The clinical differentiation of senile and arteriosclerotic psychoses. Am J Psychiatry 1941;98:324-33.

31 Roman GC. Lacunar dementia. In: Hutton JT, Kenny AD, eds. Senile Dementia of the Alzheimer's Type. New York: Alan R. Liss, Inc., 1985:1-21.

32 De Reuck T, Crevits L, DeCoster W, Sieben G, Vander Eecken H. Pathogenesis of Binswanger chronic progressive subcortical encephalopathy. Neurology 1980;30:920-8.

33 Fisher CM. Lacunar strokes and infarcts: a review. Neurology 1982;32:871-6.

34 Kinkel WR, Jacobs L, Polachini I, Bates V, Heffner RR Jr. Subcortical arteriosclerotic encephalopathy (Binswanger's disease). Computed tomographic, nuclear magnetic resonance, and clinical correlations. Arch Neurol 1985;42:951-9.

35 Emerson TR, Milne JR, Gardner AJ. Cardiogenic dementia-a myth? Lancet 1981;ii;743-4.

36 Romanul FCA, Abramowicz A. Changes in brain and pial vessels in arterial border zones. Arch Neurol 1964;11:40-65.

37 Torvik A. The pathogenesis of watershed infarcts in the brain (Editorial). Stroke 1984;15;221-3.

38 Ginsberg MD, Hedley-Whyte ET, Richardson EP Jr. Hypoxicischemic leukoencephalopathy in man. Arch Neurol 1976;33:5-14.

39 Editorial. Cardiogenic dementia. Lancet 1977;1:27-8.

40 Roth $M$. The natural history of mental disorder in old age. $J$ Ment Sci 1955;101:281-301.

41 Hontela S, Schwartz G. Myocardial infarction in the differential diagnosis of dementias in the elderly. $J$ Am Geriatr Soc 1979;27:104-6.

42 Clair DST, Whalley LJ. Hypertension, multi-infarct dementia and Alzheimer's disease. Br J Psychiatry 1983;143:274-6.

43 Loeb C, Gadolfo C. Diagnostic evaluation of degenerative and vascular dementia. Stroke 1983;14:399-401.

44 Gustafson L, Nilsson L. Differential diagnosis of presenile dementia on clinical grounds. Acta Psychiatr Scand 1982; 65:194-209. 